\title{
Investigating Sustainability-oriented Practices in Malaysian Oil Palm Cooperatives: A Construct Validation Method Using Confirmatory Composite Analysis
}

\section{Zaifalaila Zakaria, Abdul Rahman Abdul Rahim and Zaki Aman}

To Link this Article: http://dx.doi.org/10.6007/IJARBSS/v11-i5/8523

DOI:10.6007/IJARBSS/v11-i5/8523

Received: 02 March 2021, Revised: 05 April 2021, Accepted: 15 April 2021

Published Online: 10 May 2021

In-Text Citation: (Zakaria et al., 2021)

To Cite this Article: Zakaria, Z., Rahim, A. R. A., \& Aman, Z. (2021). Investigating Sustainability-oriented Practices in Malaysian Oil Palm Cooperatives: A Construct Validation Method Using Confirmatory Composite Analysis. International Journal of Academic Research in Business and Social Sciences, 11(5), 3962.

\section{Copyright: (c) 2021 The Author(s)}

Published by Human Resource Management Academic Research Society (www.hrmars.com)

This article is published under the Creative Commons Attribution (CC BY 4.0) license. Anyone may reproduce, distribute, translate and create derivative works of this article (for both commercial and non-commercial purposes), subject to full attribution to the original publication and authors. The full terms of this license may be seen at: http://creativecommons.org/licences/by/4.0/legalcode

Vol. 11, No. 5, 2021, Pg. 39 - 62 


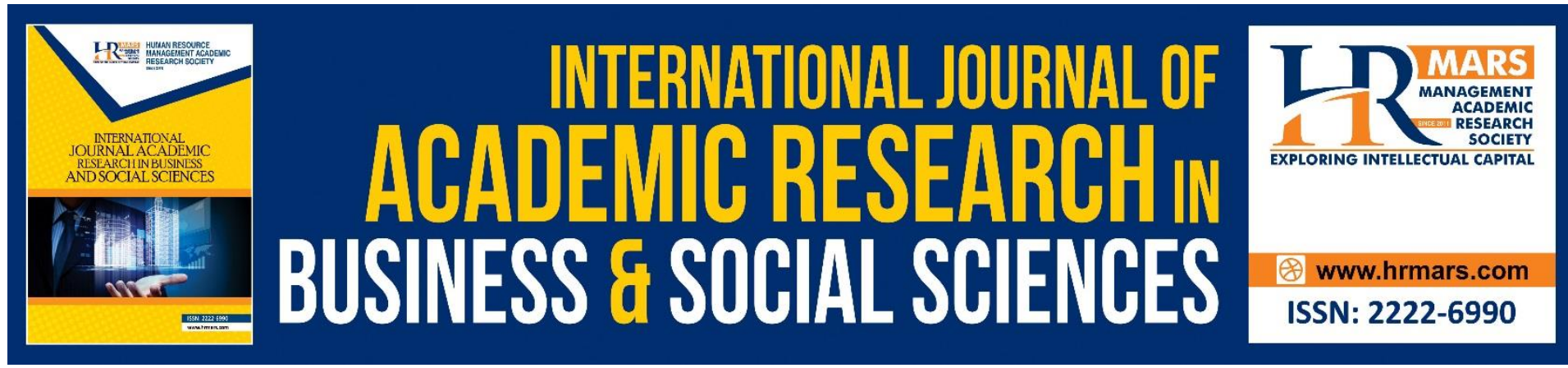

\title{
Investigating Sustainability-oriented Practices in Malaysian Oil Palm Cooperatives: A Construct Validation Method Using Confirmatory Composite Analysis
}

\author{
Zaifalaila Zakaria ${ }^{1}$, Abdul Rahman Abdul Rahim² and Zaki \\ $\mathrm{Aman}^{3}$ \\ ${ }^{1}$ Faculty of Business and Management, Universiti Teknologi MARA, Shah Alam, Malaysia, \\ ${ }^{2}$ Arshad Ayub Graduate Business School, Universiti Teknologi MARA, Shah Alam, Malaysia \\ ${ }^{3}$ Malaysian Palm Oil Board, Bangi, Malaysia
}

\begin{abstract}
Sustainability-oriented Practices (SOP) is a novel theme in the developing countries, particularly in the context of oil palm cooperatives. However, limited knowledge is observed about the achievements of sustainability agenda in oil palm cooperatives. Oil palm cooperatives are democratically controlled and voluntarily member-owned business to assist smallholders in managing their oil palm farms. This study concentrates on oil palm cooperatives because of the numerous sustainability conundrums, such as deforestation, and biodiversity endangerment, associated with this sector, and the dearth of the holistic SOP that applies to the smallholders to mitigate these issues. Consequently, the hierarchical component model of SOP is not properly proven, and this warrants the crucial need for a comprehensive method and homogenous classification of measures. This study aims to estimate and validate the SOP of oil palm cooperatives by confirming SOP as a higher-order component in the context of the Malaysian palm oil sector. Data was obtained from 185 board members of the oil palm cooperatives. Consequently, this data was analysed using confirmatory composite analysis (CCA) following a visible trend in applying partial least squares structural equation modelling (PLS-SEM). Substantial results were drawn from the CCA, therefore justifying the higher-order component of SOP. The first and second level reliability and validity assessment revealed that oil palm cooperatives implemented SOP, with varying levels of consideration to social, economic, and environmental dimensions. Environmental dimension emerged as the least critical, while the social dimension is the most prioritised. This study contributes to the sustainability, cooperative, and palm oil sector literature by presenting the earliest studies of its kind that focus on sustainability of oil palm cooperatives using a hierarchical component model. This study shed new light on the phenomena of sustainability orientation that portrays SOP as pertinent to enhance the resilience of the oil palm cooperatives.
\end{abstract}


Keywords: Hierarchical Component Model, Higher-Order Construct Validation, Overseeing Sustainability-Oriented Practices in Oil Palm Cooperatives, Malaysia

\section{Introduction}

The mounting interest and demand for sustainability-oriented practices (SOP) have triggered the evolution of studies on adopting and overseeing sustainability in diverse organisational and business entities. Sustainability is not epiphany in the present business environment. Scholars, policymakers and industries have continuously debated sustainability since the highlevel meeting of the World Commission on Environment and Development (WCED) in 1987 (Svensson et al., 2016). This has urged most business organisations to embrace sustainability practices in their reporting, which informed stakeholders how sustainability practices would enhance business reputation and performance. The same applies to the cooperatives, which is defined as a voluntary group of persons who own or govern a business that delivers benefits according to the use or ownership that generally belongs to the members equally (Altman, 2010).

Cooperatives have a crucial and dual-pronged role by satisfying their members' social need while achieving viable profits. Indeed, cooperatives receive ever-growing attention recently given their critical roles to achieve the Sustainable Development Goals (SDGs) by 2030 (Abdul Aris et al., 2018; UN, 2017). Previous studies (Abdul Aris et al., 2018; Marcis, Pinheiro de Lima, et al., 2019; Ismail et al., 2019) argued that cooperatives should embrace sustainability in their operations. These studies' critical sentiments are how cooperatives should respond to sustainability demand and pressures by adopting cost-effective practices and balancing the three constituents of sustainability following the Elkington's (1998) triple bottom line framework, encompassing social, economy, and environmental dimensions simultaneously. Unfortunately, the cooperatives' sustainability practices only gained limited interest by the policymakers, given their gradually stagnant performance (Abdul Aris et al., 2018; Janius, 2019). Although, there are literature that examines the sustainability orientation and phenomenon in cooperatives, yet most of these studies suggest the conceptual and design perspective (Abdul Aris et al., 2018; Marcis, Bortoluzzi, et al., 2019; Mohammad Ismail et al., 2019) while the validation of the second-order sustainability construct based on the three dimensions is undermined. Furthermore, organisation measures sustainability in its operations from a multifaceted environmental accounting, as well as technology-dominated perspectives such as sustainability innovations, amount of greenhouse gases generated, waste recycled or reused and energy used (Bae \& Smardon, 2011; Wijethilake, 2017).

However, these measures are unreasonable in small and micro-size cooperatives that do not have sufficient expertise and resources. Consequently, the literature on the operationalisation of sustainability in the cooperatives is still debatable because most do not measure the social, economic, and environmental dimensions simultaneously, but these were studied separately or in pairs. It is thus crucial to map and organise the theoretical grounded on the constituents of sustainability in cooperatives, as suggested by Marcis, Bortoluzzi, et al. (2019). Accordingly, more research on these aspects will provide new insights in formulating holistic measurement of SOP as a higher-order construct by integrating the social, economic, and environmental dimensions.

A review of the sustainability literature in the cooperative context shows that integrating SOP in the cooperative's operations is crucial, as it is pertinent to ensure the cooperative's longevity (Abdul Aris et al., 2018; Marcis, Bortoluzzi, et al., 2019). Another crucial part is that among the studies on cooperatives' sustainability published; very little is known about the 
SOP in Malaysia's oil palm cooperatives. Accordingly, this study identifies a research gap on how a cooperative practically implements SOP while achieving its dual-pronged objectives, members' benefits, and profitability.

Although there are diverse types of cooperatives have been established to serve their members' needs, we focus our analysis to the oil palm cooperatives. One credible reason for this selection is because numerous sustainability conundrums, particularly on environmental and labour issues, have been associated with the palm oil sector (Cramb \& McCarthy, 2017; Pye, 2018). This is evidenced when recently, the US prohibited palm oil import from the Malaysian company due to the allegation of forced labour practice (Nikkei Asia, 2021). To mitigate the allegation that negatively affect the palm oil industrial players, including the oil palm cooperatives, more concerted and different SOP approaches are urgently needed. This provides an opportunity to narrow the sustainability research gap in oil palm cooperative while strengthening Malaysia's position as the sustainable palm oil producer globally (Nambiappan et al., 2018; Zakaria et al., 2020). Thus, this study's practical contributions will help policymakers to formulate the palatable implementation of SOP as a basis for policy framework. This policy framework will pave the sustainable future, especially to the oil palm cooperatives that consist of the vulnerable smallholders who are always regarded as the Achilles heel of the palm oil sector (Hutabarat et al., 2019; Jelsma et al., 2019).

This study does not propose a completely new measurement, rather it merges the diverse and crucial constituents of sustainability dimensions based upon the practices of the corporate social responsibility perspective, as postulated by many scholars (Cegarra-Navarro et al., 2016; Gallardo-Vázquez \& Sanchez-Hernandez, 2014; Reverte et al., 2016). It offers conceptual, methodological, and operational insights to use SOP as a higher-order construct by adapting the CSR method or construct estimation to determining SOP in oil palm cooperatives. Building upon the reasoning mentioned above, the objective of this study is to examine, conceptualise, and validate the SOP based on triple bottom line (TBL) framework as a higher-order construct using the confirmatory composite analysis (CCA) technique that is available with partial least square structural equation modelling (PLS-SEM).

Following the above general introduction to the importance of SOP in oil palm cooperatives, in the second section the authors enlighten the theoretical basis of SOP construct and sustainability dimensions in the second section. The third section specifies the research methodology. The fourth section systematically presents the results of the CCA technique. The fifth section reviews and discusses the results based on the sustainability literature and oil palm smallholders' sustainability efforts. The last section crystallises the conclusion, contributions, limitations of this study and suggestions for future research agenda.

\section{Theoretical Basis of Sustainability-oriented Practices (SOP) Construct}

It is pertinent to understand the conceptualisation of sustainability before discussing the concept and practices of sustainability in the palm oil sector, or more precisely, in oil palm cooperatives. The fundamental theory of the sustainability concept is nothing new. John Elkington (1998) has coined conceptualisation of sustainability as the integration and the needs of long term balance between three dimensions, namely economic, social, and environment or (TBL) or 3Ps (People, the Planet, and Profit). Thus far, the plethora of empirical studies have examined the positive and significant outcome of multi-dimensional practices of sustainability as predictors on various business performance, in terms of capital investment (Lourenço et al., 2012), stock market and accounting performance (Eccles et al., 2011), and competitive advantages (Atkin et al., 2012; Cantele \& Zardini, 2018; Gutiérrez- 
Martínez \& Duhamel, 2019).Subsequently, sustainability practices generate better revenues due to resource optimisation, positively impacting the public sentiments that foster business competitiveness. The term sustainability practices in this research is used synonymously with the term SOP. For this study, the term SOP is the focus of interest and shall be used consistently.

In response to sustainability challenges, the attention received on this subject mostly focuses on large firms (for example; Fernando et al., 2019; Høgevold et al., 2015; Laskar \& Gopal Maji, 2018b; Laurell et al., 2018; Rauter et al., 2018; Wiengarten \& Longoni, 2015; Wijethilake, 2017). While, the sustainability studies in the context of cooperatives (Abdul Aris et al., 2018; Burjorjee et al., 2017; Mohammad Ismail et al., 2019; Mojo et al., 2015; Riva \& Garavaglia, 2016) received only limited attention although, cooperative holds a substantial role in the sustainability agenda.

In the context of the oil palm cooperatives, they play a critical role in supporting the implementation of SOP among the smallholders, although the scholarly literature on managing SOP in the oil palm cooperatives' context is still in its infancy. For instance, existing studies (Abazue et al., 2015, 2019; Ador et al., 2016; Begum et al., 2018; Choy \& Albanya, 2017; Umaira et al., 2017) have been found to debate on the sustainability of oil palm smallholders in Malaysia which is grounded around the Elkington's (1998) approach. Among those studies, one study included conceptual and reviewed studies based upon secondary data (Ador et al., 2016), three studies conducted the data analysis using a descriptive statistic, and frequency count without emphasising on reliability and validity of the measurement indicators and sustainability construct (Abazue et al., 2015; Begum et al., 2018; Umaira et al., 2017) and one study confines its focus to one specific dimension of sustainability (Choy \& Albanya, 2017). Inspired by these studies, it is paramount to offer more empirical evidence and holistic approach to validate SOP as a higher-order construct that absolutely portray the fundamental nature of sustainability in the context of oil palm cooperatives.

Furthermore, a considerable amount of literature accessible on sustainability practices concentrated on business entities such as large firms and multinational corporations in manufacturing and services industry (Crutzen, 2011; Kähkönen et al., 2018; Sroufe \& Gopalakrishna-Remani, 2018; Yu \& Zhao, 2015) rather than focusing on the cooperative sector. Additionally, Laurell et al. (2019) and Göran Svensson et al. (2016) measured the business sustainability practices according to each dimension of sustainability separately rather than one single higher-order construct. Their studies signified the phenomenon and impact of the individual dimension of sustainability independently or perhaps an approach to avoid the measurement challenges in terms of reliability and validity of a hierarchical component model that consider all the three TBL dimensions comprehensively.

In tandem with sustainability hypothetical, CSR refers to organisational behaviours and strategies that consider stakeholders' interests to balance social, economic and environmental efforts (Aguinis \& Glavas, 2012). Given the SOP and CSR conceptualisation involving similar multi-dimensional TBL approaches, scholars and practitioners have been normally considered them interchangeably and complementary (Aguinis \& Glavas, 2012; Fassin \& Van Rossem, 2009; Ullah et al., 2020). For this study, the multi-dimensional SOP construct is conceptualised as the oil palm cooperative's efforts to execute and implement activities that not only focusing on revenues but also to strike a balance between the environmental, social and economic impacts on the market and society at large (Göran Svensson et al., 2016). To understand the crux of sustainability in oil palm cooperatives, a 
brief conceptualisation and dimensionality of the SOP construct together with the challenges summarised in each of them is discussed in the following subsection.

\section{Definition, Conceptualisation and Dimensionality of the SOP Construct Social Dimension}

The social aspect of sustainability relates to the social practices that have broadened the business's responsibilities to diverse stakeholders, including employees and the community in addition to its conventional obligations to economic shareholders (Bodhanwala \& Bodhanwala, 2018). This aspect implies that social practices of a business corporation are commonly related to its sustainable growth which benefits its employees and society. Concerning the social dimension of sustainability, certain items are characterised as the social dimension of SOP, such as labour practices and decent works, human rights and social wellbeing (GRI, 2015). These items are also applied to the cooperative, which is recognised as the social enterprise that aims to fulfil its members' collective needs and not just for profitability. In the context of oil palm cooperatives as the subject of interest, it was postulated that the social dimension of sustainability practices is segmented in terms of improvement of social position, the betterment of the quality of life, healthcare security, the quality of education incentives, and participation in decision making (Abazue et al., 2015). Inspired by their study, the social dimension of SOP in cooperative is conceptualised based upon the implementation of practices that meet the members, employees, and the community's social needs without compromising other sustainability dimensions. Among the social dimension items that will be observed in this study are the employment opportunity for disabled people and the feeling of togetherness for all members.

\section{Economic Dimension}

A business entity has practised economic sustainability to reflect its business achievements towards attaining a long-term and sound financial position. In a similar vein, a business must obtain an exceptional financial accomplishment (profitability), a greater financial position (liquidity and solvency), and vigorous support from the stakeholders for its longevity and future survival (Bruwer et al., 2018). In other words, when businesses are improving their economic achievement, it creates opportunities to enhance the social betterment and environmental protection aspects undertaken by the business simultaneously.

From the perspective of oil palm cooperatives, cooperative formation contributed to the local economic system by consolidating oil palm produced by their members and selling to the millers with better prices than individual ownership (Ador et al., 2016). Consequently, the increment of oil palm prices sold by the cooperative helps the smallholders to have a better income. Additional income is also received by the smallholders as a member of the cooperative through annual dividend and bonuses. Due to this line of reasoning, the economic dimension is conceptualised as the implementation of practices by cooperative that meet its members' economic needs and others with the intention of its future business survival. These practices weighted on the efforts that foster oil palm cooperative's operations and revenue. Among the items considered in this study under the economic dimension of SOP, is whether the cooperative is committed to job creation.

\section{Environmental Dimension}

The environmental dimension of SOP denotes an environmental standpoint of the business that leads to the impact on the earth, natural ecosystem and the stakeholders' inclination 
towards this matter (Svensson \& Wagner, 2015). Environmental protection is commonly focused on product/process dematerialisation and decarbonisation, waste disposal minimisation, emission/pollution abatement, green procurement, as well as recycling and remanufacturing of materials continuously (Dos Santos et al., 2014; Goran Svensson et al., 2016; Wijethilake, 2017; Xiao et al., 2018). In this sense, all businesses have initiated many practices that affect the whole business network and supply chain to reduce their impact upon the environment.

In the case of oil palm plantation, it has been linked with the deforestation due to the extensive conversion of tropical rainforests to oil palm monocultures and the loss of biodiversity which includes the endangerment of high-valued species such as orangutan particularly in Borneo (Cramb \& Curry, 2012; Cramb \& McCarthy, 2017). In response to the environmental issues related to oil palm plantation, cooperative's members are under enormous pressure to adhere to and obtain the sustainability certification scheme for their oil palm farms because their limited financial and technical capacity (Hutabarat et al., 2019; Kumaran, 2019; Senawi, 2019). In Malaysia, it was empirically revealed that majority of the oil palm smallholders were concerned about environmental impacts but could not do more because they needed to plant and grow oil palm to support and care for their dependents (Abazue et al., 2015). Along this line of discussion, the environmental dimension of SOP for this study is conceptualised as the implementation of practices by cooperative for environment preservation and compliance with palm oil sustainability certification. For this study, the environmental dimension of SOP includes the efforts undertaken by cooperative to minimise environmental impacts and support its members to obtain palm oil sustainability certification.

\section{Research Methodology}

This study used non-probability purposive sampling to select the oil palm cooperatives and the board members as the oil palm cooperatives' representative. A non-probability purposive sampling technique was utilised to ensure the sample data characteristics matched this study's objectives and scope. The purposive sampling method was also adopted in previous studies on the cooperatives' performance and membership participation (Sallehhuddin et al., 2017; Susanty et al., 2018; Yacob et al., 2018). Hence, the selection of oil palm cooperatives and each oil palm cooperatives' board members as the sample is according to specific criteria. The two criteria concerning the board members; firstly, they should hold the board member position such as treasurer, secretary, or ordinary board members; and secondly, they should have the knowledge on the sustainability efforts in their cooperatives, farms or plantations. Board members as the respondents were considered appropriate due to their sound knowledge on cooperatives and responsible for the cooperatives' success, as posited by previous scholars (Anderson \& Henehan, 2003; Kari \& Othman, 2008; Othman et al., 2013). For oil palm cooperatives, this research chooses the Sustainable Oil Palm Growers Cooperatives (KPSM) registered with Malaysia Cooperative Societies Commission (MCSC) and under the purview of Malaysian Palm Oil Board (MPOB). The oil palm cooperative consists of the independent oil palm smallholder who have the farm area less than 100 acres (40.46 hectares) (Kumaran, 2019).

A survey was conducted to collect data from the oil palm cooperatives' board members from October 2020 to December 2020. Unit of analysis was at the organisational level and not individual. The sample size was determined by $\mathrm{G}^{*}$ Power software, considering a detection power of $80 \%$ when the magnitude effect size in the population is $15 \%$ and given statistical 
significance level of 5\%, as proposed by Kock and Hadaya (2018). The sample size generated by the software was 85 cases. The previous survey on cooperative performance in Malaysia implied response rate between $40 \%$ to $80 \%$ (Hafizah Hammad Ahmad Khan et al., 2016; Janudin et al., 2019; Yacob et al., 2018). Thus, with the estimates of $40 \%$ as anticipated response rate, the sample size to meet a minimum sample size of 85 should be about 212 . The data collection strategy allowed four responses for every oil palm cooperative, as there were 63 throughout Malaysia, and thus the questionnaires distributed were 252.

A questionnaire to observe the construct was adapted to meet the operations of the oil palm cooperative from published literature (Gallardo-Vázquez \& Sanchez-Hernandez, 2014), as illustrated in Table 1. This study used a 5-point Likert scale from $1=$ "strongly agree", to $5=$ "strongly disagree" to measure all items. Based on TBL conceptual considerations, the interactions between indicators and their lower-order components indicate a reflective specification whereby the higher-order components would be measured with the same indicators as the lower-order components, following repeated indicator approach (Sarstedt et al., 2019). Additionally, the second-order design of the SOP construct postulates that all lower-order dimensions are crucial yet complementing representations of SOP and consistent with the theoretical view.

The first version of the questionnaire was submitted to five autonomous experts who shared their views and comments separately for content validity. Then pilot study was conducted to 30 board members. This procedure is pertinent to ensure the constructs and items are relevant in the oil palm cooperative's context, to affirm the items represent an accurate sample of the theoretical construct and to identify themes on the questions are consistent with cooperative principles and values (Hardesty \& Bearden, 2004). The result of content validity and pilot study only require for minor amendment which implied the measurement is acceptable for the actual survey. 
Table 1

Questionnaire items

\begin{tabular}{|c|c|c|c|}
\hline \multirow{2}{*}{$\begin{array}{l}\text { Dimensions } \\
\text { Social }\end{array}$} & \multirow{2}{*}{$\begin{array}{l}\text { Themes } \\
\text { Decent } \\
\text { livelihood }\end{array}$} & \multicolumn{2}{|l|}{ Items } \\
\hline & & SOC1 & $\begin{array}{l}\text { The cooperative is committed to improve the } \\
\text { quality of life of its members. }\end{array}$ \\
\hline & Solidarity & SOC2 & $\begin{array}{l}\text { The cooperative has successfully created the } \\
\text { feeling-of-togetherness among its members. }\end{array}$ \\
\hline & $\begin{array}{l}\text { Human } \\
\text { safety and } \\
\text { health }\end{array}$ & SOC3 & $\begin{array}{l}\text { The cooperative complies with common standards } \\
\text { related to labour risks, health, safety, and hygiene } \\
\text { programmes. }\end{array}$ \\
\hline & $\begin{array}{l}\text { Capacity } \\
\text { development }\end{array}$ & SOC4 & $\begin{array}{l}\text { The cooperative provides professional development } \\
\text { programs for the employees to improve their } \\
\text { performance }\end{array}$ \\
\hline & Equity & SOC5 & $\begin{array}{l}\text { The cooperative has a policy also to employ } \\
\text { underprivileged people. }\end{array}$ \\
\hline & $\begin{array}{l}\text { Social } \\
\text { responsibility }\end{array}$ & SOC6 & $\begin{array}{l}\text { The cooperative supports social projects for the } \\
\text { community (for example: donation). }\end{array}$ \\
\hline \multirow[t]{4}{*}{ Environment } & $\begin{array}{l}\text { Reduction of } \\
\text { waste }\end{array}$ & ENV1 & $\begin{array}{l}\text { The oil palm waste (for example: empty fresh fruit } \\
\text { bunches and fronds) is beneficial for other } \\
\text { purposes. }\end{array}$ \\
\hline & $\begin{array}{l}\text { Sustainability } \\
\text { certification }\end{array}$ & ENV2 & $\begin{array}{l}\text { The cooperative supports its members in obtaining } \\
\text { palm oil sustainability certifications. }\end{array}$ \\
\hline & $\begin{array}{l}\text { Biodiversity } \\
\text { protection }\end{array}$ & ENV3 & $\begin{array}{l}\text { If the members find endangered species such as an } \\
\text { elephant or orangutan, they have been told to } \\
\text { inform the authority. }\end{array}$ \\
\hline & $\begin{array}{l}\text { Reduction of } \\
\text { air pollution }\end{array}$ & ENV4 & The cooperative does not practice open burning. \\
\hline \multirow[t]{6}{*}{ Economic } & $\begin{array}{l}\text { Product } \\
\text { quality }\end{array}$ & EC1 & $\begin{array}{l}\text { The cooperative is committed to offer high quality } \\
\text { oil palm fresh fruit bunches (FFB). }\end{array}$ \\
\hline & $\begin{array}{l}\text { Stability of } \\
\text { supply }\end{array}$ & $\mathrm{EC2}$ & $\begin{array}{l}\text { The farm input can be obtained from this } \\
\text { cooperative consistently. }\end{array}$ \\
\hline & $\begin{array}{l}\text { Local } \\
\text { economy }\end{array}$ & EC3 & $\begin{array}{l}\text { The cooperative offers better-priced FFB to the } \\
\text { members compared to the one offered by the } \\
\text { competitor. }\end{array}$ \\
\hline & $\begin{array}{l}\text { Product } \\
\text { information }\end{array}$ & EC4 & $\begin{array}{l}\text { The cooperative provides accurate information } \\
\text { about the FFB. }\end{array}$ \\
\hline & $\begin{array}{l}\text { Fair trading } \\
\text { practices }\end{array}$ & EC5 & $\begin{array}{l}\text { The cooperative fosters strategic business } \\
\text { relationships with FFB and farm input suppliers for } \\
\text { mutual benefits. }\end{array}$ \\
\hline & $\begin{array}{l}\text { Value } \\
\text { creation }\end{array}$ & EC6 & The cooperative is committed to job creation. \\
\hline
\end{tabular}

For this study, partial least square structural equation modelling (PLS-SEM) was utilised to focus on the CCA technique. The software of SmartPLS 3.2.8 was used to analyse the measurement model consistent with the recent guidelines (Hair et al., 2020; Sarstedt et al., 
2019). Importantly, PLS-SEM guides to theoretical parsimony and reduced difficulty when assessing the hierarchical model. Compared to confirmatory factor analysis (CFA), CCA is an alternative approach that has several benefits such as applied to confirm both reflective and formative of established measures that are being adapted to a different domain, the numbers of items retained to measure the construct are higher, thus improving content validity, convergent validity and discriminant validity (Hair et al., 2019, 2020). Given the several benefits, CCA is decisively chosen to confirm measurement models, as presented in the next section.

\section{Results and Analysis \\ Preliminary Data Analysis}

From these 252 questionnaires which were distributed to the board members of the oil palm cooperatives, 186 board members participated by completing the survey form, which makes a response rate of $73.8 \%$. The data was initially screened with missing value analysis and signified that the missing values occurred at random. Due to small sample sizes, missing values of each item not exceeding $5 \%$ for each construct were treated using a mean of each item involved to fill the missing data (Hair et al., 2017). For this case, the respondents were retained because the mean was used during the analysis in exchange. In the SOP construct, there was one outlier that has been identified from case number 140 and has been removed for further analysis. There are no suspicious respondents' response patterns that indicated respondents' willingness to engage in this study. Therefore, only 185 responses or $73.4 \%$ were suitable for analysis. The authors conducted a collinearity test to clarify if there was any construct with variance inflation factor (VIF) values of equal or exceed than 3.3 (Kock, 2015), and the results demonstrated that VIF for all items achieved satisfactory values, verifying that common method bias did not imply validity threat.

\section{Construct Validation}

In order to validate the hierarchical component model for SOP, a PLS algorithm with factor weighting scheme and 300 iterations were run to assess the four series of actions, indicator reliability, composite reliability, convergent validity and discriminant validity.

\section{Indicator Loadings}

The assessment of the indicator loadings to determine the indicators that emerged to establish a certain construct. Hair et al. (2017) corroborated that the consistent outer loadings value must be higher than 0.708 . The result of first and second algorithms to assess indicator loadings are exhibited in Table 2. For outer loadings between 0.4 and 0.70 , the removal of the indicators is considered when it leads to an increase in the average variance extracted (AVE) (Hair et al., 2017). In this case, item EC1 removed due to low outer loading (0.55) less than 0.708. Other items are retained given that the AVE values have achieved satisfactory value, more than 0.5 , as illustrated in Figure 1. 


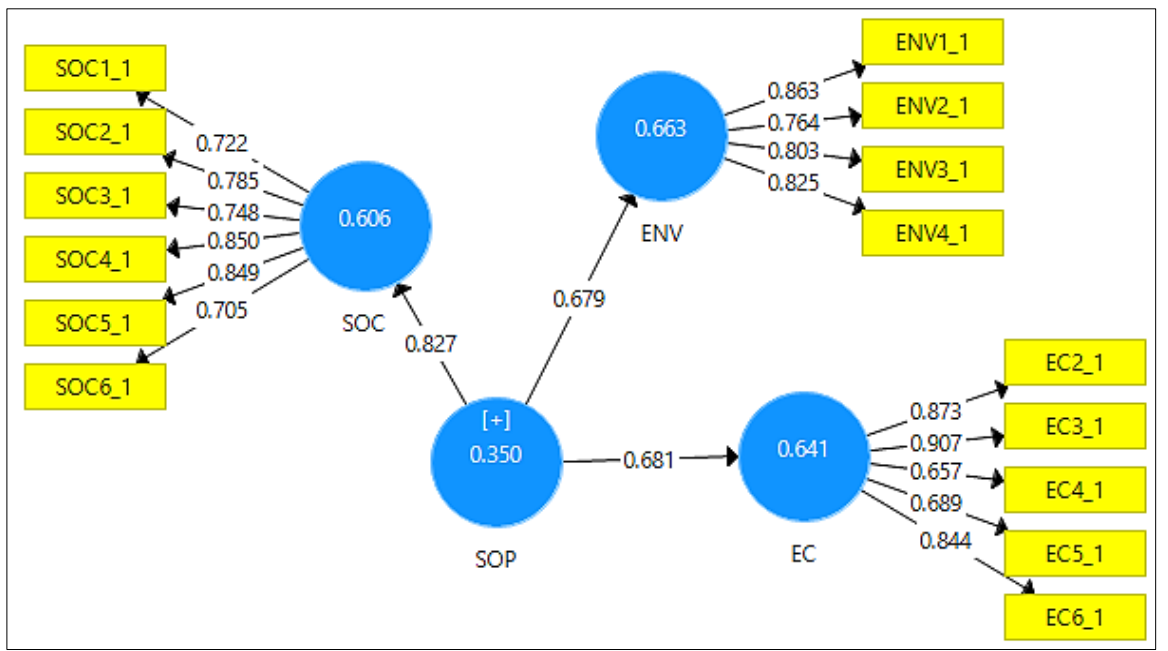

Figure 1. Measurement model with AVE values and outer loadings

Table 2

Indicator loadings

\begin{tabular}{llll}
$\begin{array}{l}\text { Dimensions of SOP } \\
\text { construct }\end{array}$ & Items & First Algorithm & $\begin{array}{l}\text { Second Algorithm } \\
\text { (Item EC1 removed) }\end{array}$ \\
\hline Economic (EC) & EC1 & 0.550 & - \\
& EC2 & 0.785 & 0.873 \\
& EC3 & 0.811 & 0.907 \\
& EC4 & 0.755 & 0.657 \\
& EC5 & 0.629 & 0.689 \\
& EC6 & 0.753 & 0.844 \\
\hline Environment & ENV1 & 0.862 & 0.863 \\
(ENV) & ENV2 & 0.763 & 0.764 \\
& ENV3 & 0.806 & 0.803 \\
& ENV4 & 0.824 & 0.825 \\
\hline Social & SOC1 & 0.727 & 0.722 \\
(SOC) & SOC2 & 0.781 & 0.785 \\
& SOC3 & 0.742 & 0.748 \\
& SOC4 & 0.855 & 0.850 \\
& SOC5 & 0.854 & 0.849 \\
& SOC6 & 0.698 & 0.705 \\
\hline
\end{tabular}

\section{Internal Consistency Reliability}

The estimation of the reliability based on the intercorrelations of the observed indicator variables for internal consistency reliability based on Cronbach's alpha (CA) value between 0.7 to 0.9 (Cronbach, 1946). This implies that values above 0.7 are considered acceptable, and values above 0.8 are excellent. Similarly, a construct is considered to have satisfactory internal consistent reliability when the composite reliability exceeds the 0.7 value. Table 3 presents the CA and composite reliability for each dimension has exceeded the threshold value. 
Table 3

Loadings, internal consistency reliability and convergent validity

\begin{tabular}{lllll}
\hline $\begin{array}{l}\text { Dimensions of } \\
\text { SOP Construct }\end{array}$ & Loadings & Cronbach's $\boldsymbol{\alpha}$ & $\begin{array}{l}\text { Composite } \\
\text { reliability, } \boldsymbol{\rho}_{\boldsymbol{c}}\end{array}$ & $\begin{array}{l}\text { Average variance } \\
\text { extracted (AVE) }\end{array}$ \\
\hline EC & $0.657-0.907$ & 0.854 & 0.898 & 0.641 \\
ENV & $0.764-0.863$ & 0.830 & 0.887 & 0.663 \\
SOC & $0.705-0.850$ & 0.870 & 0.902 & 0.606 \\
\hline
\end{tabular}

\section{Convergent Validity}

Convergent validity is crucial to assess the extent to which a measure correlates positively with other measures of the same construct using different indicators (Hair et al., 2017). To evaluate the convergent validity of reflective constructs, researchers examined the indicators' outer loadings to determine the AVE from each construct (Hair et al., 2017). Therefore, the indicators (measures) of a specific reflective construct should explain more than half of the variances. For this study, convergent validity would be based upon two approaches: (i) outer loadings of reflective construct and (ii) AVE value should exceed the threshold value of 0.5 (see Figure 1). Table 3 exhibits the value of AVE extending from 0.606 to 0.663 , which exceeded the suggested threshold value of 0.5 .

\section{Discriminant Validity}

As observed in this study, the discriminant validity must be attained to ensure the specific construct is empirically distinctive and represents a phenomenon not portrayed by any other construct in the model (Hair et al., 2017). This study evaluated the discriminant validity using three approaches: (i) cross loadings, (ii) Fornel and Larcker criterion, and HeterotraitMonotrait (HTMT) ratio.

\section{Cross-Loadings}

The cross-loadings are the first approach to assess discriminant validity based on the designated construct's outer loadings values must be greater than the outer loadings of other constructs in the model. Table 4 exhibits the cross-loadings values of other constructs lower than their loadings on the designated constructs. 
Table 4

Cross-loadings result

\begin{tabular}{llll}
\hline & EC & ENV & SOC \\
\hline EC2 & $\mathbf{0 . 8 7 3}$ & 0.258 & 0.122 \\
EC3 & $\mathbf{0 . 9 0 7}$ & 0.250 & 0.136 \\
EC4 & $\mathbf{0 . 6 5 7}$ & 0.158 & 0.537 \\
EC5 & $\mathbf{0 . 6 8 9}$ & 0.439 & 0.146 \\
EC6 & $\mathbf{0 . 8 4 4}$ & 0.212 & 0.099 \\
ENV1 & 0.254 & $\mathbf{0 . 8 6 3}$ & 0.254 \\
ENV2 & 0.302 & $\mathbf{0 . 7 6 4}$ & 0.225 \\
ENV3 & 0.241 & $\mathbf{0 . 8 0 3}$ & 0.328 \\
ENV4 & 0.277 & $\mathbf{0 . 8 2 5}$ & 0.300 \\
SOC1 & 0.238 & 0.182 & $\mathbf{0 . 7 2 2}$ \\
SOC2 & 0.224 & 0.270 & $\mathbf{0 . 7 8 5}$ \\
SOC3 & 0.131 & 0.256 & $\mathbf{0 . 7 4 8}$ \\
SOC4 & 0.289 & 0.321 & $\mathbf{0 . 8 5 0}$ \\
SOC5 & 0.297 & 0.320 & $\mathbf{0 . 8 4 9}$ \\
SOC6 & 0.112 & 0.227 & $\mathbf{0 . 7 0 5}$ \\
\hline
\end{tabular}

*after item EC1 removed

\section{Fornell-Larcker Criterion}

The second approach to determine discriminant validity by using the Fornell-Larcker criterion. This approach signified that the AVE's square root must be higher than its highest correlation with other constructs to achieve discriminant validity, as illustrated in Table 5.

\section{Table 5}

Fornell-Larcker criterion result

\begin{tabular}{llll}
\hline & EC & ENV & SOC \\
\hline EC & $\mathbf{0 . 8 0 0}$ & - & - \\
ENV & 0.329 & $\mathbf{0 . 8 1 4}$ & - \\
SOC & 0.286 & 0.342 & $\mathbf{0 . 7 7 9}$ \\
\hline
\end{tabular}

\section{Heterotrait-Monotrait Ratio}

Recently HTMT ratio is proposed as an alternative approach to determine discriminant validity given the Fornell-Larcker criterion, and cross loadings evaluation do not reliably detect discriminant validity (Henseler et al., 2015). To mitigate this issue, Henseler et al. (2015) suggest using the HTMT ratio, referring to the HTMT correlations values relative to the average of the heterotrait-heteromethod correlations. To achieve discriminant validity, the HTMT values should not exceed the threshold values of 0.85 and 0.90 (Hair et al., 2017; Henseler et al., 2015). Table 6 shows that discriminant validity is achieved for all the constructs based on HTMT inference. 
Table 6

Heterotrait-Monotrait (HTMT) criterion result

\begin{tabular}{llll}
\hline & EC & ENV & SOC \\
\hline EC & - & - & - \\
ENV & 0.400 & - & - \\
SOC & 0.300 & 0.400 & - \\
\hline
\end{tabular}

\section{Assessing Second-order Construct}

The approach for assessing second-order construct in PLS-SEM uses repeated indicator approach, as Sarstedt et al. (2019) recommended. The recommendation is followed by calculating SOP as type 1 second-order (reflective-reflective) construct (Jarvis et al., 2003; Sarstedt et al., 2019). Sarstedt et al. (2019) posited that the internal consistency reliability assessment of the SOP as the second-order constructs on the grounds of the 15 items (SOP1, SOP2...ENV4) was dubious. This dubious result occurred because the higher-order component's measurement model repeats the indicators of its lower-order components (Sarstedt et al., 2019). Hence, this study manually calculated the relevant statistics for assessing the SOP'S composite reliability as the second-order constructs based on their respective indicators loadings (Sarstedt et al., 2019). The results produce loadings of 0.827 for SOC, 0.681 for EC and 0.679 for ENV, as exhibited in Figure 1. These loadings thereby providing input for composite reliability, can be manually calculated:

$$
\rho c=\frac{\left(\sum_{i=1}^{M} I_{i}\right)^{2}}{\left(\sum_{i=1}^{M} I_{i}\right)^{2}+\sum_{i=1}^{M} \operatorname{var}\left(e_{i}\right)}
$$

This calculation describes $e_{i}$ as the measurement error of the first-order component, $l$, and $\operatorname{var}\left(e_{i}\right)$ indicates the variance of the measurement error, which is defined as $1-l_{i}^{2}$. Entering the loadings of SOP dimensions, namely SOC (0.827), EC (0.681) and ENV (0679) yields the following, composite reliability for SOP as a higher-order construct:

$$
\begin{gathered}
\left.S O P \rho c=\frac{(0.827+0.681+0.679)^{2}}{(0.827+0.681+0.679)^{2}+\left(1-0.827^{2}\right)+\left(1-0.681^{2}\right)+\left(1-0.679^{2}\right)}\right) \\
S O P \rho c=\frac{4.78}{4.78+0.316+0.536+0.539}=0.775
\end{gathered}
$$

Similarly, the convergent validity of the SOP as the second-order construct on the grounds of the 15 items were not meaningful given it uses the same indicators for first and second-order construct (Sarstedt et al., 2019). With this regard, this research manually calculated the convergent validity of SOP as the second-order constructs based on their respective indicators loadings (Sarstedt et al., 2019). The results produced loadings of 0.827 for SOC, 0.681 for EC and 0.679 for ENV, as exhibited in Figure 1. Sarstedt et al. (2019) suggested that the AVE can be manually calculated by using these indicator loadings as input:

$$
A V E=\frac{\left(\sum_{i=1}^{M} I_{i}^{2}\right)}{M}
$$

By entering the loading of the first-order component I of a specific second-order component measured with $M$ first-order components, for this SOP second-order construct, the AVE is 
$\left(0.827^{2}+0.681^{2}+0.679^{2}\right) / 3=0.536$. The AVE values for SOP $(0.536)$ is above the 0.5 threshold value, therefore signifying convergent validity for SOP second-order construct is achieved.

Table 7

Reliability and validity of SOP

\begin{tabular}{lllll}
\hline Construct & Dimensions & Loadings & $\begin{array}{l}\text { Composite } \\
\text { reliability, } \\
\boldsymbol{\rho}_{\boldsymbol{c}}\end{array}$ & AVE \\
\hline \multirow{3}{*}{ SOP } & EC & 0.681 & & \\
& ENV & 0.679 & 0.775 & 0.536 \\
& SOC & 0.827 & & \\
\hline
\end{tabular}

The reliability and validity results for second-order SOP construct is revealed in Table 7 . The CR (0.775), and AVE (0.536) values of the SOP signified that the second-order construct validation has significantly established.

\section{Discussion}

The validity and reliability conditions have been successfully met which affirmed the SOP construct in the context of oil palm cooperatives is valid and will lead to a formulation of the parsimonious model in determining the social, economic and environmental aspects of sustainability simultaneously (refer Table 2-7). At the first order, this study provides empirical evidence on the three constituents of the economic, social, and environmental dimensions of SOP by achieving a satisfactory level in terms of CR, CA, factor loadings, AVE and HTMT values, which confirms the authenticity of the measurement model. The results have shown that across the three dimensions, it is clearly indicated that the social dimension of SOP exhibited the strongest loadings. This could be attributed to the fact that cooperatives as a part of social enterprises must prioritise pertaining to the social needs of their members, namely improving the quality of lives and cohesiveness among the members of the cooperatives, emphasising the professional, health and safety of their workforce while promoting social responsibility in their own communities in terms of donation and creating employment to the underprivileged. This result is in line with Marcis, Pinheiro de Lima, et al. (2019) who revealed that the social dimension of sustainability is in the DNA of the cooperatives for use in the formulation of sustainability strategies for agricultural cooperatives. This result also echoed with Dale et al. (2013), who observed that the social dimension of sustainability was stronger than the environmental and economic dimensions, although other sustainability dimensions (economic and environment) were present in the cooperative.

In the same investigation, the economic dimension of SOP emerged as the second most influential element in oil palm cooperative. One plausible reason for this result given that the highlighted economic dimension signified on important indicators. These indicators emphasise on the needs for cooperatives to have great determination and knowledge to produce higher-quality agricultural outputs with competitive prices in comparison to their rivals, and to foster a strategic partnership with suppliers while providing consistent agricultural inputs for their members. However, item EC1 is removed due to the low loading value. This implies that offering high quality oil palm to the millers is not crucial to the oil palm cooperatives, indicating that the general tendency of the free-rider problems in conventional cooperative's operation (Ortmann \& King, 2007; Soboh et al., 2009). The result also meets the indication of Marcis, Pinheiro de Lima, et al. (2019) who revealed that although the economic 
dimension has stood out in comparison to the other dimensions, there is an increasing emphasis on social and environmental dimensions.

Finally, the environmental dimension of SOP revealed the lowest loadings in oil palm cooperatives. Concerning the environmental dimension, these results underscore the cooperative's initiatives on minimising the environmental impacts by recycling the oil palm waste for other purposes, and the support provided by cooperatives in obtaining oil palm sustainability certification. Nevertheless, independent smallholders have been recognised for their environmental commitment, particularly in sustainability certification (Abazue et al., 2019; Senawi, 2019). Even though each organisation is unique, SOP based on specific indicators must be relevant to its operations and boundaries. These results suggest that validated SOP indicators will encourage the oil palm cooperatives to strive towards becoming sustainable organisations while mitigating the contemporary sustainable issues associated with global warming, climate change and desertification.

\section{Conclusion}

In conclusion, our results validated the higher-order SOP construct, although estimating and examining second-order composites poses a challenge for researchers using PLS-SEM. Concisely, this study complements and adds to previous evidence pointing to the usefulness of feasible sustainability efforts in the cooperative by indicating consistencies between the measurement model and the collected data. Furthermore, we offer a better understanding that the existence of SOP as a prior step to govern the cooperatives for future survival in overcoming the controversial sustainability issues. Thus, it is observed that the validated indicators of SOP have a potential adoption in line with postulated sustainability theory, indicating that they are adequate to be implemented as the sustainability strategies in agricultural cooperatives' operations, particularly in oil palm cooperatives.

\section{Contributions of the Study}

It is worth mentioning that this study provides various theoretical and managerial contributions. Regarding the theoretical contribution, as discussed in the introductory section, this study attempts to narrow the research gap, given that only limited previous studies have analysed business sustainability phenomenon focusing on SOP in the Malaysian cooperative context. Furthermore, our study enriches the business sustainability literature by confirming the different influences and interdependencies of SOP's dimensions, referring to the hierarchical component model. This affirms that the TBL dimension of SOP in cooperative is crucial to differing degrees, focusing on its nature, dual-pronged objectives and main concern, consistent with the notion that postulated business sustainability practices are commonly open, adaptable and iterative (Goran Svensson et al., 2016). Subsequently, we provide new insight into how to estimate and assess SOP as a higher-order construct in the context of oil palm cooperatives by employing CCA and repeated indicators approach. Therefore, this enables scholars from the sustainability and cooperative literature to properly estimate the fit of the overall measurement model encompassing higher-order construct of SOP and to determine measurement quality evaluation.

Concerning the managerial contribution, our study provides guidance to the policymakers to improve the cooperative sector's existing policy framework by embracing SOP based on the validated indicators. These indicators should be integrated into the cooperative's overarching strategic management to overcome the shortcomings of fragmented economic, social, and environmental practices. Consequently, this policy will facilitate the cooperative's managers 
to systematically implement and balance these sustainability dimensions, given that social equity, environmental protection, and economic prosperity are crucial and must be managed harmoniously. Furthermore, sustainability orientation must be aligned with universal cooperatives' principle and values, namely, social responsibility, equality, and solidarity. Subsequently, this will improve the livelihood of the smallholders and help them to mitigate sustainability impacts such as minimising the air, soil, and water pollution, protecting biodiversity, and rejecting forced or child labour incidents, thereby giving a greener image to the palm oil sector in Malaysia, resulting in greater market access and promising growth. Thus, SOP must be incorporated into an oil palm cooperative's operation, which will increase the sustainability reputation of the palm oil sector, endorsing Malaysia as the sustainable palm oil producer worldwide.

\section{Limitations and Future Lines of Research}

This study is also subjected to several notable limitations that suggest some directions for future research. This study's first limitation comes from the sampling design that focuses on the agricultural cooperative domain, specifically oil palm cooperatives. Our study decisively concentrates on this domain, given the robust market presence of agricultural cooperatives exhibit worldwide (Benos et al., 2018) and Malaysia's position as the second global oil palm producer (Gan \& Li, 2014). However, results might be improved by including other types of agricultural cooperatives in the future. The second limitation of this study about the oil palm cooperatives in Malaysia. Future researchers may also replicate this study by surveying the oil palm cooperatives in other countries such as Indonesia. A comparison through crosscountries study would help advance the novel theme of SOP in the palm oil sector. Researchers may want to examine other constructs that are connected to SOP construct such as cooperative performance as endogenous construct or cooperative's innovativeness as mediator variable. This attempt is useful to allow for the better understanding of the sustainability phenomenon in cooperative, as these constructs also have significant interest to cooperative's organisation.

Author contributions: The first, second and third authors contributed equally to this article.

Acknowledgements: The authors would like to extend a word of thanks to the anonymous reviewers from Universiti Teknologi MARA, Shah Alam, Malaysia, Department of Agricultural (DOA) Malaysia, Cooperative Societies Commission Malaysia (SKM) and National Audit Department (JAN) Malaysia, for their support, constructive and helpful comments for content validity in order to improve the earlier measurement of this construct. The authors would like to express gratitude to the oil palm cooperatives' board members for participating in the data collection process.

Funding: This study received no internal or external funding from any commercial or noncommercial source for the authorship and/or publication of this article.

Conflicts of interest: The authors declare no potential conflicts of interests. 


\section{References}

Abazue, C. M., Choy, E. A., \& Lydon, N. (2019). Oil palm smallholders and certification: exploring the knowledge level of independent oil palm smallholders to certification. $J$. Biosci. Agric. Res, 19(01), 1589-1596. https://doi.org/10.18801/jbar.190119.193

Abazue, C. M., Er, A. C., Ferdous Alam, A. S. A., \& Begum, H. (2015). Oil Palm Smallholders and Its Sustainability Practices in Malaysia. Mediterranean Journal of Social Sciences, December. https://doi.org/10.5901/mjss.2015.v6n6s4p482

Abdul Aris, N., Marzuki, M., Othman, R., Abdul Rahman, S., \& Hj Ismail, N. (2018). Designing indicators for cooperative sustainability: the Malaysian perspective. Social Responsibility Journal, 14(1), 226-248. https://doi.org/10.1108/SRJ-01-2017-0015

Ador, S. F., Siwar, C., \& Ghazali, R. (2016). A review of palm oil impact on sustainability dimension: SPOC initiative for independent smallholders. International Journal of Agriculture, Forestry and Plantation, 2(feb.), 104-110.

Aguinis, H., \& Glavas, A. (2012). What we know and don't know about corporate social responsibility. Journal of Management, 38(4), 932-968. https://doi.org/10.1177/0149206311436079

Akisik, O., \& Gal, G. (2011). Sustainability in businesses, corporate social responsibility, and accounting standards: An empirical study. International Journal of Accounting and Information Management, 19(3), 304-324.

https://doi.org/10.1108/18347641111169287

Altman, M. (2010). History and theories of cooperatives. International Encyclopedia of Civil Society Springer, New York, NY, December, 563-570.

Anderson, B. L., \& Henehan, B. M. (2003). What gives cooperatives a bad name? NCR 194 Meeting, 1-12.

Atkin, T., Gilinsky, A., \& Newton, S. K. (2012). Environmental strategy: does it lead to competitive advantage in the US wine industry? International Journal of Wine Business Research, 24(2), 115-133. https://doi.org/10.1108/17511061211238911

Bae, H., \& Smardon, R. C. (2011). Indicators of sustainable business practices. In Environmental Management in Practice (Issue May, pp. 177-206). InTech. https://doi.org/10.5772/17254

Begum, H., Siwar, C., Alam, L., Choy, E. A., Ishak, S., \& Alam, A. S. A. F. (2018). Enhancing sustainability amongst oil palm smallholders in Malaysia. International Journal of Agricultural Resources, Governance and Ecology, 14(1), 62. https://doi.org/10.1504/IJARGE.2018.10011894

Benos, T., Kalogeras, N., Wetzels, M., de Ruyter, K., \& Pennings, J. M. E. (2018). Harnessing a 'currency matrix' for performance measurement in cooperatives: A multi-phased study. Sustainability (Switzerland), 10(12), 4536. https://doi.org/10.3390/su10124536

Bodhanwala, S., \& Bodhanwala, R. (2018). Does corporate sustainability impact firm profitability? Evidence from India. Management Decision, 56(8), 1734-1747. https://doi.org/10.1108/MD-04-2017-0381

Bruwer, J. P., Coetzee, P., \& Meiring, J. (2018). Can internal control activities and managerial conduct influence business sustainability? A South African SMME perspective. Journal of Small Business and Enterprise Development, 25(5), 710-729. https://doi.org/10.1108/JSBED-11-2016-0188

Burjorjee, P., Nelis, Y., \& Roth, B. (2017). Land cooperatives as a model for sustainable agriculture: A case study in Germany. Blekinge Institute of Technology, Karlskona, Sweden. 
Cantele, S., \& Zardini, A. (2018). Is sustainability a competitive advantage for small businesses? An empirical analysis of possible mediators in the sustainability-financial performance relationship. Journal of Cleaner Production, 182, 166-176. https://doi.org/10.1016/j.jclepro.2018.02.016

Cegarra-Navarro, J.-G., Reverte, C., Gómez-Melero, E., \& Wensley, A. K. P. (2016). Linking social and economic responsibilities with financial performance: The role of innovation. European Management Journal, 34(5), 530-539. https://doi.org/10.1016/j.emj.2016.02.006

Choy, E. A., \& Albanya, A. . (2017). Economic sustainability of palm oil plantations smong smallholders in Lahad Datu, Sabah. Journal of Fundamental and Applied Sciences, 4(1), 9-10. https://doi.org/10.4314/jfas.v9i7s.8

Cramb, R., \& Curry, G. N. (2012). Oil palm and rural livelihoods in the Asia-Pacific region: An overview. Asia Pacific Viewpoint, 53(3), 223-239. https://doi.org/10.1111/j.14678373.2012.01495.x

Cramb, R., \& McCarthy, J. F. (2017). The oil palm complex smallholders, agribusiness and the state in Indonesia and Malaysia. In R. Cramb \& J. F. McCarthy (Eds.), NUS Press (First). NUS Press Pte Ltd. http://www.jstor.org/stable/10.2307/j.ctv1xz0km.7

Cronbach, L. J. (1946). A case study of the splithalf reliability coefficient. Journal of Educational Psychology, 37(8), 473-480. https://doi.org/10.1037/h0054328

Crutzen, N. (2011). Sustainability Performance Management in Large Firms: A Qualitative Research amongst Seven Western European Firms. 1-24.

https://orbi.ulg.ac.be/bitstream/2268/99001/1/FullPaper-Sustainability Performance Management-EBEN-June2011.pdf

Dale, A., Duguid, F., Lamarca, M. G., Hough, P., Tyson, P., Foon, R., Newell, R., \& Herbert, Y. (2013). Cooperatives and sustainability: An investigation into the relationship. Report International Co-Operative Alliance, 1-76.

Dos Santos, M. A. O., Svensson, G., \& Padin, C. (2014). Implementation, monitoring and evaluation of sustainable business practices: framework and empirical illustration. Corporate Governance (Bingley), 14(4), 515-530. https://doi.org/10.1108/CG-02-20130022

Duguid, F., Lamarca, M. G., Hough, P., Tyson, P., Foon, R., Newell, R., Herbert, Y., MeyerMacLeod, J., \& Jeremy Murphy. (2013). Cooperatives and sustainability: An investigation into the relationship. http://www.ssg.coophttp//ica.coop

Eccles, R. G., Ioannou, I., \& Serafeim, G. (2011). The impact of corporate sustainability on organizational processes and performance. In SSRN. https://doi.org/10.2139/ssrn.1964011

El-Khalil, R., \& El-Kassar, A. N. (2018). Effects of corporate sustainability practices on performance: the case of the MENA region. Benchmarking, 25(5), 1333-1349. https://doi.org/10.1108/BIJ-06-2015-0065

Elkington, J. (1998). Cannibals with forks. The triple bottom line of 21st century business. New Society Publishers. https://doi.org/0865713928

Esim, S. (2017). Co-operatives and the Sustainable Development Goals. www.ilo.org/coop

Fassin, Y., \& Van Rossem, A. (2009). Corporate Governance in the Debate on CSR and Ethics: Sensemaking of Social Issues in Management by Authorities and CEOs. Corporate Governance: An International Review, 17(5), 573-593. https://doi.org/10.1111/j.14678683.2009.00738.x

Fernando, Y., Jabbour, C. J., \& Wah, W. X. (2019). Pursuing green growth in technology firms 
through the connections between environmental innovation and sustainable business performance: Does service capability matter? Resources, Conservation and Recycling, 141(July 2018), 8-20.

https://doi.org/10.1016/j.resconrec.2018.09.031

Gadenne, D., Mia, L., Sands, J., Winata, L., \& Hooi, G. (2012). The influence of sustainability performance management practices on organisational sustainability performance. Journal of Accounting and Organizational Change, 8(2), 210-235.

https://doi.org/10.1108/18325911211230380

Gallardo-Vázquez, D., \& Sanchez-Hernandez, M. I. (2014). Measuring corporate social responsibility for competitive success at a regional level. Journal of Cleaner Production, 72, 14-22. https://doi.org/10.1016/j.jclepro.2014.02.051

Gan, P. Y., \& Li, Z. D. (2014). Econometric study on Malaysia's palm oil position in the world market to 2035. Renewable and Sustainable Energy Reviews, 39(June), 740-747. https://doi.org/10.1016/j.rser.2014.07.059

Gefen, Rigdon, \& Straub. (2011). Editor's Comments: An Update and Extension to SEM Guidelines for Administrative and Social Science Research. MIS Quarterly, 35(2), iii. https://doi.org/10.2307/23044042

GRI. (2015). Interpretations on the G4 Sustainability Reporting Guidelines. https://www.globalreporting.org/resourcelibrary/grig4-part1-reporting-principles-andstandard-disclosures.pdf

Grønholdt, L., \& Martensen, A. (2009). Management practices driving sustained business success. Measuring Business Excellence, 13(1), 47-55.

https://doi.org/10.1108/13683040910943045

Gutiérrez-Martínez, I., \& Duhamel, F. (2019). Translating sustainability into competitive advantage: the case of Mexico's hospitality industry. Corporate Governance: The International Journal of Business in Society, ahead-of-p(ahead-of-print). https://doi.org/10.1108/cg-01-2019-0031

Hair, Hult, G. T. M., Ringle, C. M., \& Sarstedt, M. (2017). A primer on partial least squares structural equation modeling (PLS-SEM). In SAGE Publications, Inc. (Vol. 38, Issue 2). https://doi.org/10.1080/1743727X.2015.1005806

Hair, J. F., Howard, M. C., \& Nitzl, C. (2020). Assessing measurement model quality in PLS-SEM using confirmatory composite analysis. Journal of Business Research, 109(August 2019), 101-110. https://doi.org/10.1016/j.jbusres.2019.11.069

Hair, J. F., Sarstedt, M., \& Ringle, C. M. (2019). Rethinking some of the rethinking of partial least squares. European Journal of Marketing, 53(4), 566-584. https://doi.org/10.1108/EJM-10-2018-0665

Hardesty, D. M., \& Bearden, W. O. (2004). The use of expert judges in scale development. Implications for improving face validity of measures of unobservable constructs. Journal of Business Research, 57(2), 98-107. https://doi.org/10.1016/S0148-2963(01)00295-8

Henseler, J., Ringle, C. M., \& Sarstedt, M. (2015). A new criterion for assessing discriminant validity in variance-based structural equation modeling. Journal of the Academy of Marketing Science, 43(1), 115-135. https://doi.org/10.1007/s11747-014-0403-8

Høgevold, N. M., \& Svensson, G. (2012). A business sustainability model: A European case study. Journal of Business and Industrial Marketing, 27(2), 142-151. https://doi.org/10.1108/08858621211197001

Hutabarat, S., Slingerland, M., \& Dries, L. (2019). Explaining the "Certification Gap" for Different Types of Oil Palm Smallholders in Riau Province, Indonesia. The Journal of 
Environment \& Development, 28(3), 253-281.

https://doi.org/10.1177/1070496519854505

ILO, \& ICA. (2015). Cooperatives and the sustainable development goals: A contribution to the post-2015 development debate a policy brief. International Labour Organization: International Cooperative Alliance, 1-16. www.ica.coop

Janius, J. (2019). Gerakan Koperasi di Malaysia Menongkah Kebekuan. Universiti Malaya Publisher.

Janudin, S. E., Halim, H. A., Habidin, N. F., \& Hanif, F. M. (2019). Contemporary management accounting practices and managerial performance amongst the Malaysian co-operatives sector. Research in World Economy, 10(5), 129-138.

https://doi.org/10.5430/rwe.v10n5p129

Jarvis, C. B., MacKenzie, S. B., \& Podsakoff, P. M. (2003). A critical review of construct indicators and measurement model misspecification in marketing and consumer research. Journal of Consumer Research, 30(2), 199-218.

https://doi.org/10.1086/376806

Jelsma, I., Woittiez, L. S., Ollivier, J., \& Dharmawan, A. H. (2019). Do wealthy farmers implement better agricultural practices? An assessment of implementation of Good Agricultural Practices among different types of independent oil palm smallholders in Riau, Indonesia. Agricultural Systems, 170(November 2018), 63-76. https://doi.org/10.1016/j.agsy.2018.11.004

Kähkönen, A.-K., Lintukangas, K., \& Hallikas, J. (2018). Sustainable supply management practices: making a difference in a firm's sustainability performance. Supply Chain Management: An International Journal, 23(6), 518-530. https://doi.org/10.1108/SCM01-2018-0036

Kari, F., \& Othman, A. (2008). Enhancing co-operative movement to achieve Malaysia's development goals. The Role of Co-Operatives in Sustaining Development and Fostering Social Responsibility. https://doi.org/10.1109/RFIC.2003.1213898

Khan, S. A., Kusi-Sarpong, S., Arhin, F. K., \& Kusi-Sarpong, H. (2018). Supplier sustainability performance evaluation and selection: A framework and methodology. Journal of Cleaner Production, 205, 964-979. https://doi.org/10.1016/j.jclepro.2018.09.144

Kock, N. (2015). Common method bias in PLS-SEM: A full collinearity assessment approach. International Journal of E-Collaboration, 11(4), 1-10.

https://doi.org/10.4018/ijec.2015100101

Kock, N., \& Hadaya, P. (2018). Minimum sample size estimation in PLS-SEM: The inverse square root and gamma-exponential methods. Information Systems Journal, 28(1), 227261. https://doi.org/10.1111/isj.12131

Kumaran, S. (2019). The dynamics for mandatory MSPO certification scheme to be successfully implemented. Journal of Oil Palm, Environment and Health (JOPEH), 10(0). https://doi.org/10.5366/jope.2019.01

Laskar, N., \& Maji, G. S. (2018). Disclosure of corporate sustainability performance and firm performance in Asia. Asian Review of Accounting, 26(4), 414-443. https://doi.org/10.1108/ARA-02-2017-0029

Laurell, H., Karlsson, N. P. E., Lindgren, J., Andersson, S., \& Svensson, G. (2019). Re-testing and validating a triple bottom line dominant logic for business sustainability. Management of Environmental Quality: An International Journal, 30(3), 518-537. https://doi.org/10.1108/MEQ-02-2018-0024

Lourenço, I. C., Branco, M. C., Curto, J. D., \& Eugénio, T. (2012). How does the market value 
corporate sustainability performance? Journal of Business Ethics, 108(4), 417-428. https://doi.org/10.1007/s10551-011-1102-8

Maletič, M., Maletič, D., \& Gomišček, B. (2012). An organizational sustainability performance measurement framework. Environment, Energy Systems and Sustainability, 220-225.

Marcis, J., Bortoluzzi, S. C., de Lima, E. P., \& da Costa, S. E. G. (2019). Sustainability performance evaluation of agricultural cooperatives' operations: a systemic review of the literature. Environment, Development and Sustainability, 21(3), 1111-1126. https://doi.org/10.1007/s10668-018-0095-1

Marcis, J., Pinheiro de Lima, E., \& Gouvêa da Costa, S. E. (2019). Model for assessing sustainability performance of agricultural cooperatives'. Journal of Cleaner Production, 234, 933-948. https://doi.org/10.1016/j.jclepro.2019.06.170

Mojo, D., Fischer, C., \& Degefa, T. (2015). Social and environmental impacts of agricultural cooperatives: Evidence from Ethiopia. International Journal of Sustainable Development \& World Ecology, 22(5), 388-400. https://doi.org/10.1080/13504509.2015.1052860

Nambiappan, B., Ismail, A., Hashim, N., Ismail, N., Shahari, D. N., Idris, N. A. N., Omar, N., Salleh, K. M., Hassan, N. A. M., \& Kushairi, A. (2018). Malaysia: 100 years of resilient palm oil economic performance. In Journal of Oil Palm Research (Vol. 30, Issue 1, pp. 13-25). https://doi.org/10.21894/jopr.2018.0014

Asia, N. (2021). US blocks palm oil imports from Malaysia's Sime Darby - Nikkei Asia. Nikkei Asia. https://asia.nikkei.com/Economy/Trade/US-blocks-palm-oil-imports-fromMalaysia-s-Sime-Darby

Ortmann, G. F., \& King, R. P. (2007). Agricultural cooperatives I: History, theory and problems. Agrekon, 46(1), 18-46. https://doi.org/10.1080/03031853.2007.9523760

Othman, I., Maslinawati, M., \& Azizah, A. (2013). Cooperative movements in Malaysia: The issue of governance. International Journal of Social, Educational, Economic and Management Engineering, 7(6), 660-664. https://doi.org/10.1002/jtr

Padin, C., Ferro, C., Wagner, B., Valera, J. C. S., Høgevold, N. M., \& Svensson, G. (2016). Validating a triple bottom line construct and reasons for implementing sustainable business practices in companies and their business networks. Corporate Governance (Bingley), 16(5), 849-865. https://doi.org/10.1108/CG-12-2015-0163

Pye, O. (2018). Commodifying sustainability: Development, nature and politics in the palm oil industry. World Development. https://doi.org/10.1016/j.worlddev.2018.02.014

Rauter, R., Globocnik, D., Perl-Vorbach, E., \& Baumgartner, R. J. (2018). Open innovation and its effects on economic and sustainability innovation performance. Journal of Innovation \& Knowledge, 4(4), 226-233. https://doi.org/10.1016/j.jik.2018.03.004

Reverte, C., Gómez-Melero, E., \& Cegarra-Navarro, J. G. (2016). The Influence of Corporate Social Responsibility Practices on Organizational Performance: Evidence from EcoResponsible Spanish Firms. Journal of Cleaner Production, 112, 2870-2884. https://doi.org/10.1016/j.jclepro.2015.09.128

Riva, E., \& Garavaglia, E. (2016). The sustainability and political agency of social cooperatives in Italy during the great recession. International Journal of Sociology and Social Policy, 36(7-8), 435-455. https://doi.org/10.1108/IJSSP-01-2016-0005

Sallehhuddin, A., Said, A. M. A., Hasmanto, N., Mustafa, M. A., Jais, M., Samsudin, A., Masuod, M. S., \& Ismail, H. (2017). Crafting preliminary model for mosque cooperatives' antecedents of performance. Asian Social Science, 13(2), 116. https://doi.org/10.5539/ass.v13n2p116

Sarstedt, M., Hair, J. F., Cheah, J. H., Becker, J. M., \& Ringle, C. M. (2019). How to specify, 
estimate, and validate higher-order constructs in PLS-SEM. Australasian Marketing Journal, 27(3), 197-211. https://doi.org/10.1016/j.ausmj.2019.05.003

Senawi, R. (2019). Transformation of Oil Palm Independent Smallholders Through Malaysian Sustainable Palm Oil. Journal of Oil Palm Research, 31(3), 496-507. https://doi.org/10.21894/jopr.2019.0038

Soboh, R. A. M. E., Lansink, A. O., Giesen, G., \& van Dijk, G. (2009). Performance measurement of the agricultural marketing cooperatives: The gap between theory and practice. Review of Agricultural Economics, 31(3), 446-469. https://doi.org/10.1111/j.14679353.2009.01448.x

Sroufe, R., \& Gopalakrishna-Remani, V. (2018). Management, social sustainability, reputation, and financial performance relationships: An empirical examination of U.S. firms. Organization and Environment. https://doi.org/10.1177/1086026618756611

Susanty, A., Bakhtiar, A., Puspitasari, N. B., \& Mustika, D. (2018). Performance analysis and strategic planning of dairy supply chain in Indonesia: A comparative study. International Journal of Productivity and Performance Management, 67(9), 1435-1462. https://doi.org/10.1108/IJPPM-10-2017-0250

Svensson, Göran, Høgevold, N., Ferro, C., Varela, J. C. S., Padin, C., \& Wagner, B. (2016). A Triple Bottom Line Dominant Logic for Business Sustainability: Framework and Empirical Findings. Journal of Business-to-Business Marketing, 23(2), 153-188. https://doi.org/10.1080/1051712X.2016.1169119

Svensson, Goran, Høgevold, N. M., Petzer, D., Padin, C., Ferro, C., Klopper, H. B., Sosa Varela, J. C., \& Wagner, B. (2016). Framing stakeholder considerations and business sustainability efforts: a construct, its dimensions and items. Journal of Business and Industrial Marketing, 31(2), 287-300. https://doi.org/10.1108/JBIM-05-2014-0094

Svensson, Göran, \& Wagner, B. (2015). Implementing and managing economic, social and environmental efforts of business sustainability propositions for measurement and structural models. Management of Environmental Quality: An International Journal, 26(2), 195-213. https://doi.org/10.1108/MEQ-09-2013-0099

Ullah, M., Khan, M. W. A., Hussain, A., Rana, F., \& Khan, A. (2020). A Construct Validation Approach for Exploring Sustainability Adoption in Pakistani Construction Projects. Buildings, 10(11), 207. https://doi.org/10.3390/buildings10110207

Umaira, F., Awang, A. H., Azian, M., Ibrahim, I., Ramli, Z., Lyndon, N., Yusof, I., Hashim, K., Peng, T. S., Mansor, N. H., Omar, W., Bakar, H. A., Sosial, P. K., Pembangunan, P., Sains, F., Ekonomi, F., \& Selangor, B. (2017). Kelestarian penanaman sawit dan produktiviti pekebun kecil persendirian. Journal of Global Business and Social Entrepreneurship (GBSE), 2015(1), 12-20.

UN. (2017). Cooperatives in Social Development: Report of the Secretary-General (Vol. 12080, Issue July). https://documents-dds-

ny.un.org/doc/UNDOC/GEN/N17/217/92/PDF/N1721792.pdf?OpenElement

Wiengarten, F., \& Longoni, A. (2015). A nuanced view on supply chain integration: A coordinative and collaborative approach to operational and sustainability performance improvement. Supply Chain Management, 20(2), 139-150.

https://doi.org/10.1108/SCM-04-2014-0120

Wijethilake, C. (2017). Proactive sustainability strategy and corporate sustainability performance: The mediating effect of sustainability control systems. Journal of Environmental Management, 196, 569-582.

https://doi.org/10.1016/j.jenvman.2017.03.057 
Windolph, S. E., Schaltegger, S., \& Herzig, C. (2014). Implementing corporate sustainability: What drives the application of sustainability management tools in Germany? Sustainability Accounting, Management and Policy Journal, 5(4), 374-404. https://doi.org/10.1108/SAMPJ-01-2014-0002

Xiao, C., Wang, Q., van der Vaart, T., \& van Donk, D. P. (2018). When Does Corporate Sustainability Performance Pay off? The Impact of Country-Level Sustainability Performance. Ecological Economics, 146(December 2016), 325-333. https://doi.org/10.1016/j.ecolecon.2017.11.025

Yacob, Y., Ali, J. K., Roslin, R., \& Ting, H. (2018). The relationships between member participation, trust, Behavioural loyalty, and the moderating effect of ethnicity: An explanatory study of value co-creation among cooperative members in Sarawak. International Journal of Business and Society, 19(2), 505-522.

Yu, M., \& Zhao, R. (2015). Sustainability and firm valuation: An international investigation. International Journal of Accounting and Information Management, 23(3), 289-307. https://doi.org/10.1108/IJAIM-07-2014-0050

Zakaria, Z., Rahim, A. R. A., \& Aman, Z. (2020). Issues and Challenges of Oil Palm Cooperatives towards Greater Sustainability: A Proposal of Conceptual Framework. International Journal of Academic Research in Business and Social Sciences, 10(1), 46-69. https://doi.org/10.6007/IJARBSS/v10-i1/6806 